\title{
Soil Solarization in High Tunnels in the Semiarid Southwestern United States
}

\author{
Kristen Hanson, Tilak Mahato, and Ursula K. Schuch ${ }^{1}$ \\ School of Plant Sciences, University of Arizona, Forbes Building Room 303, \\ Tucson, AZ 85721
}

Additional index words. biological control, Integrated Pest Management, plasticulture, polyethylene mulch, soil disinfestation, solar heating

\begin{abstract}
High tunnels are unheated structures covered with polyethylene (PE) glazing to protect high-value crops from adverse weather. The objective of this study was to raise soil temperatures to determine the efficacy of soil solarization using clear mulch on the soil surface and glazing or no glazing on a high tunnel during the hottest months of the year in the semiarid southwestern United States. Solarization trials were conducted in May and June 2013 in two high tunnels in southern Arizona. Highest soil temperatures were reached with the combination of a high tunnel covered with glazing and the soil covered with PE mulch. Average daily soil temperatures were 48 and $47^{\circ} \mathrm{C}$ and average degree hours (DH) per day (base temperature $45^{\circ} \mathrm{C}$ ) were over 14 at soil depths of 5 and $15 \mathrm{~cm}$. The average daily maximum soil temperature at 5- and $15-\mathrm{cm}$ depth was 63.4 and $52{ }^{\circ} \mathrm{C}$, respectively. The second highest soil temperatures were reached when the soil was covered with PE mulch without high tunnel glazing, which resulted per day in $5.2 \mathrm{DH}$ above $45^{\circ} \mathrm{C}$ at $5 \mathrm{~cm}$ and less than one DH at 15-cm depth. Glazing on the high tunnel without covering the soil surface raised soil temperatures only at the $5-\mathrm{cm}$ depth above $45^{\circ} \mathrm{C}$, but not further down. High tunnel producers in the low desert areas in the southwestern United States can complete solarization in less than 1 week, depending on the organism to be controlled, when the soil is fallow during the summer months with glazing on the high tunnel and on the soil surface.
\end{abstract}

Soil solarization uses solar radiation to disinfest the soil from pests detrimental to crop plants (Katan, 1981; Stapleton, 2000). Soil solarization is used most in areas with high solar radiation and temperatures during the summer season (Gill et al., 2009; Stapleton, 2000). It is used as an alternative to soil fumigation for pathogen and pest control either alone or in combination with fumigants (Elmore et al., 1997; Hartz et al., 1993). Disinfestation is achieved by using solar radiation to passively heat moist soil covered with clear plastic sheeting for a period of a few weeks to increase soil temperatures to the point where they are lethal to soilborne organisms (Katan, 1981; Pullman et al., 1981; Stapleton, 2000). Higher soil moisture during solarization can increase the soil heat conductivity resulting in higher temperatures compared with soil that is less moist (Katan et al., 1976). Low-density PE film and ethylene vinyl acetate film have the best solarizing properties for increasing temperatures in production beds (D'Addabbo et al., 2010). Solarization is a strategy used to reduce the

Received for publication 18 Feb. 2014. Accepted for publication 22 June 2014.

This project was partially supported by the USDA NIFA grant 2011-4940030543.

Mention of a trademark, proprietary product, or vendor does not constitute a guarantee of warranty of the product by the University of Arizona and does not imply its approval to the exclusion of other products or vendors that also may be suitable.

${ }^{1}$ To whom reprint requests should be addressed; e-mail uschuch@e-mail.arizona.edu. soilborne pests and diseases such as Verticillium dahliae (verticillium wilt), Fusarium spp. (fusarium wilt), Phytophthora cinnamomi (Phytophthora root rot), Meloidogyne incognita (root knot nematodes) and weed species (Dahlquist et al., 2007; Stapleton et al., 2000). The elevated soil temperatures are also beneficial for soil physical and chemical structure, accelerating the release of minerals from decomposition and increasing soil aggregation (Elmore et al., 1997; Stapleton, 2000).

The effectiveness of solarization is based on the actual maximum soil temperature achieved under the plastic cover and the amount of time that this temperature can be sustained (Chase et al., 1999). Soil temperatures of $37^{\circ} \mathrm{C}$ can be effective in controlling some pests and pathogens if they are maintained for 4 to 6 weeks (Elmore et al., 1997). The optimal temperature for the solarization process depends on which organisms are present in the soil and their susceptibility to high temperatures. Some organisms and their thermal thresholds for inactivation are listed in Table 1. Studies have shown a logarithmic relationship between temperature and pathogen mortality where less time is required to kill pests and disease-causing organisms as soil temperature increases (McLean et al., 1999; Pullman et al., 1981). In laboratory studies, pathogens such as Verticillium dahliae, Pythium ultimum, and Thielaviopsis basicola required 29, 18, and $33 \mathrm{~d}$ to kill $90 \%$ of propagules at $37{ }^{\circ} \mathrm{C}$, respectively (Pullman et al., 1981). However, at $50{ }^{\circ} \mathrm{C}$ those times were reduced to 23,33 , and $68 \mathrm{~min}$. Temperatures of $50{ }^{\circ} \mathrm{C}$ or greater dramatically reduce the amount of time required to inactivate various pest organisms (Dahlquist et al., 2007; Mihail and Alcorn, 1984; Pullman et al., 1981; Stapleton et al., 2000).

Solarization in a greenhouse or high tunnel structure will yield higher soil temperatures than in fields or gardens (Elmore et al., 1997). Using PE mulch inside a greenhouse will further increase the effectiveness of the soil solarization process (Mahrer et al., 1987), especially in cooler coastal climates (Larson, 2007). Although temperatures in soils covered with PE mulch will be highest in a glass house, a structure with PE glazing will also be effective in raising soil temperatures above mulched soil exposed to open air conditions. Soil solarizaion in a Mediterranean climate using $\mathrm{PE}$ mulch for 7- to 9-week intervals was successful in raising soil temperatures at $15-\mathrm{cm}$ depth between 37 and $50{ }^{\circ} \mathrm{C}$ in beds used for strawberry (Fragaria xananassa Duch.) cultivation under plastic tunnel conditions (Iapichino et al., 2008). Solarization in a high tunnel in Costa Rica increased the soil temperature of covered soil to $\approx 60{ }^{\circ} \mathrm{C}$ compared with $30{ }^{\circ} \mathrm{C}$ for uncovered soil (Santos et al., 2008). A double-tent system within a greenhouse facilitated structural solarization by raising temperatures to $60{ }^{\circ} \mathrm{C}$ and resulted in effective inactivation of Fusarium sp. (Shlevin et al., 2004). The same temperature was effective in killing weed species in containers filled with soil and exposed to solarization in a double tent (Stapleton et al., 2002). At present there are no studies for the semiarid southwestern United States region comparing solarization inside and outside of a high tunnel. One goal of this study was to provide growers using high tunnels with information that may be beneficial to protecting their crops from weed and other pest populations.

The semiarid climate in southern Arizona is ideal for soil solarization as a result of high solar radiation. June is the optimal time for solarization because the daily solar radiation can reach $30 \mathrm{MJ} \cdot \mathrm{m}^{-2}$ and temperatures are higher for this month than others [Arizona Meteorological Network (AZMET), 2013; Mihail and Alcorn, 1984]. In Tucson, AZ, daily fluctuations in temperature are typically 8 to $17{ }^{\circ} \mathrm{C}$ with June average highs and lows of $38{ }^{\circ} \mathrm{C}$ and 21 to $27^{\circ} \mathrm{C}$, respectively (AZMET). Although these are averages, temperatures can reach extreme highs such as $47^{\circ} \mathrm{C}$ in June of 1990 . Low relative humidity during early summer months combined with high temperatures and high solar radiation provides growers with an opportunity for using solarization when production areas are fallow. The objective of this study was to determine the efficacy of clear PE mulch on the soil surface and glazing on a high tunnel to raise soil temperatures to solarize the soil during the hottest time of the year in the semiarid southwestern United States.

\section{Materials and Methods}

Two high tunnels with the dimensions of $4.3 \mathrm{~m}$ width, $12.8 \mathrm{~m}$ length, and $2.1 \mathrm{~m}$ height 
Table 1. Temperature and time period required for the inactivation of some pests

\begin{tabular}{|c|c|c|c|}
\hline \multicolumn{2}{|c|}{ Organism } & $\begin{array}{c}\text { Treatments to } \\
\text { inactivate organism }\end{array}$ & Literature citation \\
\hline$\overline{\text { Amaranthus albus }}$ & Tumble pigweed & $\begin{array}{l}1 \mathrm{~h} \text { at } 60^{\circ} \mathrm{C} \\
20 \text { min at } 70^{\circ} \mathrm{C}\end{array}$ & Stapleton et al., 2000 \\
\hline Aphanomyces cochlioides & Black leg & $72 \mathrm{~h}$ at $45^{\circ} \mathrm{C}$ & Dyer et al., 2007 \\
\hline Botrytis cinerea & Grey mold & $\begin{array}{l}20 \text { min at } 46.4^{\circ} \mathrm{C} \\
2 \text { min at } 49^{\circ} \mathrm{C}\end{array}$ & Lichter et al., 2003 \\
\hline Echinochloa crus-galli & Barnyard grass & $\begin{array}{l}15 \mathrm{~h} \text { at } 46^{\circ} \mathrm{C} \\
9 \mathrm{~h} \text { at } 50^{\circ} \\
15 \mathrm{~min} \text { at } 60^{\circ} \mathrm{C}\end{array}$ & Dahlquist et al., 2007 \\
\hline Macrophomina phaseolina & Charcoal rot & $\begin{array}{l}72 \mathrm{~h} \text { at } 45^{\circ} \mathrm{C} \\
48 \mathrm{~h} \text { at } 50{ }^{\circ} \mathrm{C} \\
24 \mathrm{~h} \text { at } 55^{\circ} \mathrm{C}\end{array}$ & Mihail and Alcorn, 1984 \\
\hline Meloidogyne incognita & Root knot nematode & $1 \mathrm{~h}$ at $45^{\circ} \mathrm{C}$ & Wang and McSorely, 2008 \\
\hline Pythium ultimum & Pythium root rot & $20 \mathrm{~min}$ at $46^{\circ} \mathrm{C}$ & Baker and Cummings, 1943 \\
\hline Phytophthora cactorum & Blight, damping off & $30 \mathrm{~min}$ at $45^{\circ} \mathrm{C}$ & Juarez-Palacios et al., 1991 \\
\hline Phytophthora capsici & Phytophthora blight & $\begin{array}{l}22 \mathrm{~h} \text { at } 45^{\circ} \mathrm{C} \\
4.7 \mathrm{~h} \text { at } 50^{\circ} \mathrm{C} \\
1 \mathrm{~h} \text { at } 53^{\circ} \mathrm{C}\end{array}$ & Etxeberria et al., 2011 \\
\hline $\begin{array}{l}\text { Phytophthora cinnamomi } \\
\text { Phytophthora megasperma }\end{array}$ & Blight, damping off & $20 \mathrm{~min}$ at $45^{\circ} \mathrm{C}$ & Juarez-Palacios et al., 1991 \\
\hline Phythophthora nicotianae & Blight, damping off & $2 \mathrm{~h}$ at $45^{\circ} \mathrm{C}$ & Coelho et al., 2000 \\
\hline Phytophthora rubi & Raspberry root rot & $52 \mathrm{~h}$ at $35^{\circ} \mathrm{C}$ & Pinkerton et al., 2009 \\
\hline Portulaca olerace & Common purselane & $\begin{array}{l}3 \mathrm{~h} \text { at } 60^{\circ} \mathrm{C} \\
20 \text { min at } 70{ }^{\circ} \mathrm{C}\end{array}$ & Stapleton et al., 2000 \\
\hline Rhizoctonia solani & $\begin{array}{l}\text { Stem and Stolon } \\
\text { Canker }\end{array}$ & $5 \mathrm{~min}$ at $50^{\circ} \mathrm{C}$ & Sherwood, 1970 \\
\hline Sclerotium cepivorum & Sclerotinia rot & $\begin{array}{l}48 \mathrm{~h} \text { at } 40.7^{\circ} \mathrm{C} \\
24 \mathrm{~h} \text { at } 41.9^{\circ} \mathrm{C} \\
12 \mathrm{~h} \text { at } 45.2^{\circ} \mathrm{C} \\
6 \mathrm{~h} \text { at } 47.4^{\circ} \mathrm{C}\end{array}$ & McLean et al., 1999 \\
\hline Sclerotium rolfsii & Southern blight & $\begin{array}{l}12 \mathrm{~h} \text { at } 45^{\circ} \mathrm{C} \\
6 \mathrm{~h} \text { at } 50^{\circ} \mathrm{C} \\
3 \mathrm{~h} \text { at } 55^{\circ} \mathrm{C}\end{array}$ & Mihail and Alcorn, 1984 \\
\hline Solanum nigrum & Black nightshade & $\begin{array}{l}2 \mathrm{~h} \text { at } 60^{\circ} \mathrm{C} \\
20 \text { min at } 70{ }^{\circ} \mathrm{C}\end{array}$ & Stapleton et al., 2000 \\
\hline Solanum nigrum & Black nightshade & $\begin{array}{l}213 \mathrm{~h} \text { at } 46^{\circ} \mathrm{C} \\
71 \mathrm{~h} \text { at } 50^{\circ} \mathrm{C} \\
2 \mathrm{~h} \text { at } 60^{\circ} \mathrm{C}\end{array}$ & Dahlquist et al., 2007 \\
\hline Sonchus oleraceus & Annual sowthistle & $\begin{array}{l}4 \mathrm{~h} \text { at } 50^{\circ} \mathrm{C} \\
15 \mathrm{~min} \text { at } 60^{\circ} \mathrm{C}\end{array}$ & Dahlquist et al., 2007 \\
\hline Verticillium dahliae & Verticillium wilt & $40 \mathrm{~min}$ at $47^{\circ} \mathrm{C}$ & Nelson and Wilhelm, 1958 \\
\hline
\end{tabular}

located at the Campus Agricultural Center in Tucson, AZ, were used for this experiment. Each structure had two growing beds with dimensions of $1.2 \mathrm{~m} \times 11.5 \mathrm{~m}$ divided by a path along the center. The growing beds were amended with compost in 2012 and raised soil organic matter to $\approx 3.5 \%$. Glazing (152.4 $\mu \mathrm{m}$ IR/AC polyethylene; GreenTek, Visalia, CA) was kept on each of the two high tunnels from 24 May 2013 through 5 June 2013 for solarization of the beds. Each high tunnel was constructed with end walls with working doors and vent windows that were kept closed during solarization. One half of each of the beds was covered with $25.4 \mu \mathrm{m}$ solid, clear PE mulch, which contained an ultraviolet stabilizer that prevented degradation from solar radiation for $180 \mathrm{~d}$ (Water Tech, Charlotte, NC) and the other half remained uncovered. Each bed was thoroughly irrigated using six drip tapes per bed with $10-\mathrm{cm}$ spacing of emitters at a rate of $0.60 \mathrm{~L} \cdot \mathrm{h}^{-1}$ for each dripper for $1 \mathrm{~h}$ (Jain Irrigation Inc., Watertown, NY). The water was allowed to drain through the beds for $1 \mathrm{~h}$ after which the cycle was repeated. The irrigation lines were removed from the beds before covering the soil surface with the PE mulch.

The 25.4- $\mu \mathrm{m}$ PE mulch was placed directly on the beds keeping the film smooth against the soil surface to eliminate any air pockets. Edges of the film were held down with lumber to prevent any air from entering underneath and drying the soil in the beds. Thermocouples were placed in each covered and uncovered soil area in each high tunnel at depths of $5 \mathrm{~cm}$ and $15 \mathrm{~cm}$ to record the temperature every $15 \mathrm{~min}$ (HOBO U12 4-Channel External Data Logger; Onset was placed $15 \mathrm{~cm}$ above the soil at the center of each tunnel to record the air temperature every $15 \mathrm{~min}$. This sensor was not shielded and aspirated and higher recorded air temperatures may be the result of exposure to long wave radiation. Solar radiation data and ambient outside air temperature were collected from sensors $1.5 \mathrm{~m}$ above the soil at the AZMET station located $\approx 200 \mathrm{~m}$ from the experimental site. Solar radiation is measured and reported as average Langleys per hour. These units were converted to average hourly and average daily MJ.m². On 31 May 2013, the PE mulch was removed from the beds. Irrigation lines were redeployed and the irrigation process was repeated before replacing the thermocouples. The beds were covered again with the PE mulch and the solarization process was repeated from 1 June to 6 June 2013. Corp., Bourne, MA). One temperature sensor
On 10 June 2013, the glazing was removed from one of the high tunnels for a comparison of temperatures in a high tunnel with glazing with open-field conditions. This was done to compare soil temperatures in the same soil conditions as in the hoop house because no comparable soil was available outside the hoop houses. The same methods as described were used for soil irrigation and soil solarization. Soil and air temperatures were collected from 11 to 17 June and from 18 to 23 June 2013. On 17 June, the PE mulch was removed, irrigation applied, and the soil covered again with PE mulch. Treatments were designated as high tunnels with the glazing on or glazing off and soil covered with PE mulch or soil uncovered.

Temperatures collected during a time period at the same soil depth of two replicate beds within a tunnel under each solarization treatment were averaged and the $\mathrm{DH}$ above 45,50 , or $55{ }^{\circ} \mathrm{C}$ were determined for each 24-h period. Temperature differences between covered and uncovered soil were calculated. A regression was calculated between the soil temperatures at $5-\mathrm{cm}$ and 15-cm depth in soil covered with PE mulch in a glazed tunnel as a function of the ambient temperature.

\section{Results}

The hourly solar radiation for two periods during the month of June 2013 is shown in Figure 1. From 1 to 6 June, high solar radiation levels prevailed as a result of clear skies. From 11 to 16 June, cloud cover decreased solar radiation levels on some days.

Soil solarization with the glazing on the high tunnel and the beds covered with a PE mulch resulted in the highest temperatures for the longest duration at $5 \mathrm{~cm}$ and $15 \mathrm{~cm}$ (Table 2; Fig. 2). From 24 May 2013 through 23 June 2013, the soil at a depth of $5 \mathrm{~cm}$ and $15 \mathrm{~cm}$ reached on average $14.8 \mathrm{DH}$ per day over $45^{\circ} \mathrm{C}$ (Table 2 ). Figure 2 shows daily air and soil temperature fluctuations for a $5-\mathrm{d}$ period when glazing covered the high tunnels. Outside air temperatures reached up to $40{ }^{\circ} \mathrm{C}$ and air temperatures in the covered high tunnel climbed to $70{ }^{\circ} \mathrm{C}$ (Fig. 2A). Similar AZMET and air temperatures in the closed tunnel were monitored during the second week of June (Fig. 3A). During the entire study, diurnal air temperature fluctuation outside was $20^{\circ} \mathrm{C}$ and inside the tunnel $50{ }^{\circ} \mathrm{C}$ (Figs. 2A and 3A). Daily soil temperatures oscillated $\approx 30{ }^{\circ} \mathrm{C}$ at 5 -cm depth in covered soil and $20^{\circ} \mathrm{C}$ in uncovered soil (Fig. 2B). Less fluctuation was observed at $15-\mathrm{cm}$ depth with the least change in soil temperature in uncovered soil (Fig. 2B). Covering the soil in the glazed high tunnel raised temperatures at $5-\mathrm{cm}$ depth between 15 and $18{ }^{\circ} \mathrm{C}$ during the warmest part of the day compared with uncovered soil and $\approx 13$ to $14{ }^{\circ} \mathrm{C}$ at 15-cm depth (Fig. 2C).

A linear regression equation predicted the soil temperature at $5-\mathrm{cm}$ depth in a tunnel with glazing and with soil covered with $\mathrm{PE}$ 

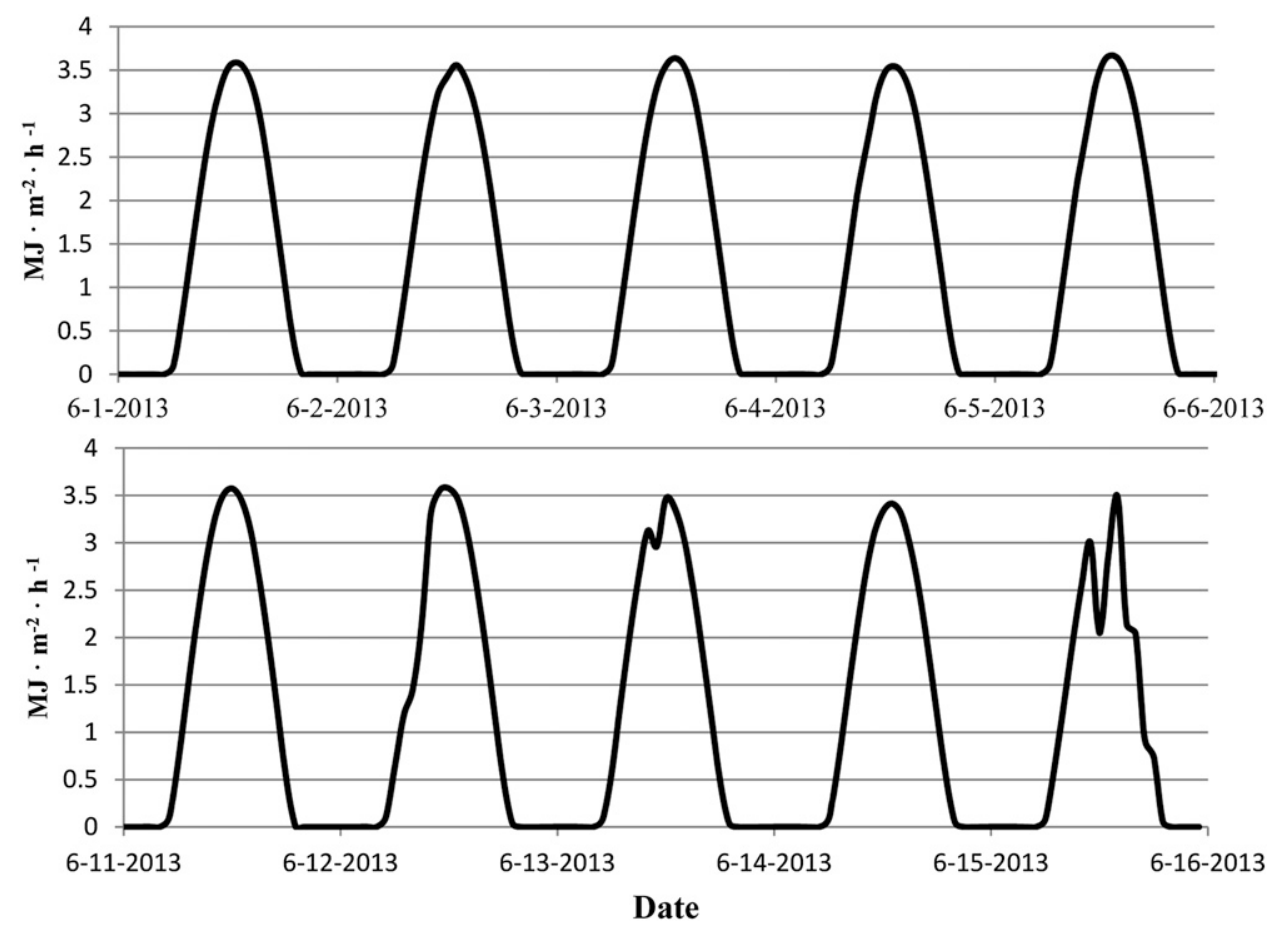

Fig. 1. Solar radiation from 1 to 5 June 2013 and 11 to 15 June 2013.

Table 2. Daily maximum and average soil temperatures and degree hours above 45,50 , and $55^{\circ} \mathrm{C}$ in high tunnels with or without glazing and in soil covered with plastic mulch or without from 24 May to 23 June 2013.

\begin{tabular}{|c|c|c|c|c|c|c|c|}
\hline \multirow{2}{*}{$\begin{array}{l}\text { High tunnel } \\
\text { glazing }\end{array}$} & \multirow{2}{*}{$\begin{array}{l}\text { Soil } \\
\text { glazing }\end{array}$} & \multirow{2}{*}{$\begin{array}{c}\text { Soil } \\
\text { depth }(\mathrm{cm})\end{array}$} & \multirow{2}{*}{$\begin{array}{c}\text { Avg daily } \\
\text { maximum temp }\left({ }^{\circ} \mathrm{C}\right)\end{array}$} & \multirow{2}{*}{$\begin{array}{l}\text { Avg daily } \\
\text { temp }\left({ }^{\circ} \mathrm{C}\right)\end{array}$} & \multicolumn{3}{|c|}{ Degree hours } \\
\hline & & & & & $>45{ }^{\circ} \mathrm{C}$ & $>50^{\circ} \mathrm{C}$ & $>55^{\circ} \mathrm{C}$ \\
\hline On & On & 15 & 52.0 & 47.0 & $14.9(0.13)$ & $6.3(0.12)$ & 0 \\
\hline Off & On & 5 & 54.3 & 41.4 & $8.2(0.28)$ & $5.5(0.17)$ & $0.3(0.23)$ \\
\hline Off & On & 15 & 44.2 & 40.4 & $0.7(0.13)$ & 0 & 0 \\
\hline Off & Off & 5 & 40.7 & 32.3 & 0 & 0 & 0 \\
\hline
\end{tabular}

${ }^{\mathrm{z}}$ Average (SE).

mulch as a function of the ambient air temperature as follows:

$$
\begin{aligned}
& \text { Soil temperature }\left({ }^{\circ} \mathrm{C}\right) \text { at } 5 \mathrm{~cm} \text { depth } \\
& =10.86+1.27 \\
& \times\left(\text { ambient AZMET temperature }\left({ }^{\circ} \mathrm{C}\right)\right. \\
& \quad\left(\mathrm{R}^{2}=0.77\right)
\end{aligned}
$$

A linear regression of soil temperature at $15-\mathrm{cm}$ depth under the same conditions resulted in a poor fit (data not presented).

Solarization with the high tunnel glazing off and mulch covering the beds sustained temperatures above $45^{\circ} \mathrm{C}$. Results showed an average of $8.2 \mathrm{DH}$ a day over $45^{\circ} \mathrm{C}$ at a depth of $5 \mathrm{~cm}$ but less than one DH a day at $15-\mathrm{cm}$ depth (Table 2). The highest soil temperature achieved at $5 \mathrm{~cm}$ was $55.8{ }^{\circ} \mathrm{C}$ (data not shown). Degree hours above 50 and $55{ }^{\circ} \mathrm{C}$ were 5.5 and 0.3 at $5 \mathrm{~cm}$ but $\mathrm{PE}$ mulch on the soil alone did not raise temperatures above these values at $15-\mathrm{cm}$ depth (Fig. 3B). Covered and uncovered soil temperatures in open air conditions fluctuated $\approx 20$ and $10^{\circ} \mathrm{C}$ daily at 5-cm and 15-cm depth (Fig. 3B). Plastic mulch on the soil raised temperatures at $5-\mathrm{cm}$ depth between 6 to $17^{\circ} \mathrm{C}$ (Fig. 3C).

Leaving the glazing on the high tunnel and no PE mulch on the soil surface resulted only in $5.2 \mathrm{DH}$ over $45^{\circ} \mathrm{C}$ at $5 \mathrm{~cm}$ and $0 \mathrm{~h}$ at 15-cm depth (Table 2). Daily maximum temperatures at $5 \mathrm{~cm}$ were almost $15{ }^{\circ} \mathrm{C}$ less than when high tunnel glazing and soil glazing were installed and only up to $8{ }^{\circ} \mathrm{C}$ warmer than in bare soil.

Bare soil without glazing on the high tunnels and the beds uncovered did not reach soil temperatures of $45^{\circ} \mathrm{C}$ at any depth (Fig. $3 \mathrm{~B})$. At $5-\mathrm{cm}$ depth the highest temperature was $42.8^{\circ} \mathrm{C}$ and the average temperature was $32.3{ }^{\circ} \mathrm{C}$.

\section{Discussion}

The most effective solarization strategy was to keep the glazing on the high tunnels in conjunction with a $25.4-\mu \mathrm{m}$ PE cover on the well-irrigated beds. When daily solar radiation averaged $29.8 \mathrm{MJ} \cdot \mathrm{m}^{-2}$ and outside temperatures reached $38{ }^{\circ} \mathrm{C}$, the soil at $5-\mathrm{cm}$ depth exceeded 45 and $55^{\circ} \mathrm{C}$ for almost $15 \mathrm{~h}$ and $8 \mathrm{~h}$, respectively, each day. This treatment resulted in a significant period each day when temperatures exceeded the thresholds to effectively kill many soil pathogens, pests, and weeds in a relatively short time (Katan, 1981; Mihail and Alcorn, 1984; Pullman et al., 1981). Maintaining the glazing on high tunnels was especially beneficial for raising the soil temperature at $15-\mathrm{cm}$ depth where temperatures above $45^{\circ} \mathrm{C}$ were maintained for almost $15 \mathrm{~h}$ daily and thus control potential pathogens or pests to a greater depth. Although monitored only for a total of $20 \mathrm{~d}$, AZMET temperatures during the hottest part of the year could be used to predict soil temperatures at a depth of $5 \mathrm{~cm}$ in covered beds in a hoop house with glazing.

Solarization in a clear plastic tunnel in coastal California raised soil temperatures significantly and led to improved weed control compared with solarized soil without the tunnel (Larson, 2007). Solarization under plastic tunnels in Italy raised soil temperatures above $45{ }^{\circ} \mathrm{C}$ at $15-\mathrm{cm}$ depth for 72 cumulative hours over a period of $50 \mathrm{~d}$ from 


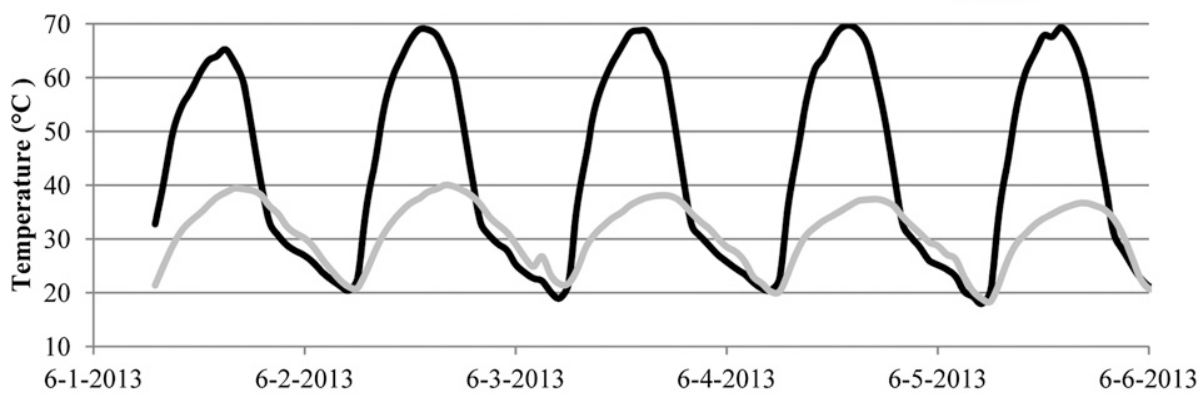

B. Soil Temperature

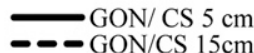

$-0 \mathrm{GON} / \mathrm{CS} 15 \mathrm{~cm}$ GON/UCS $5 \mathrm{~cm}$

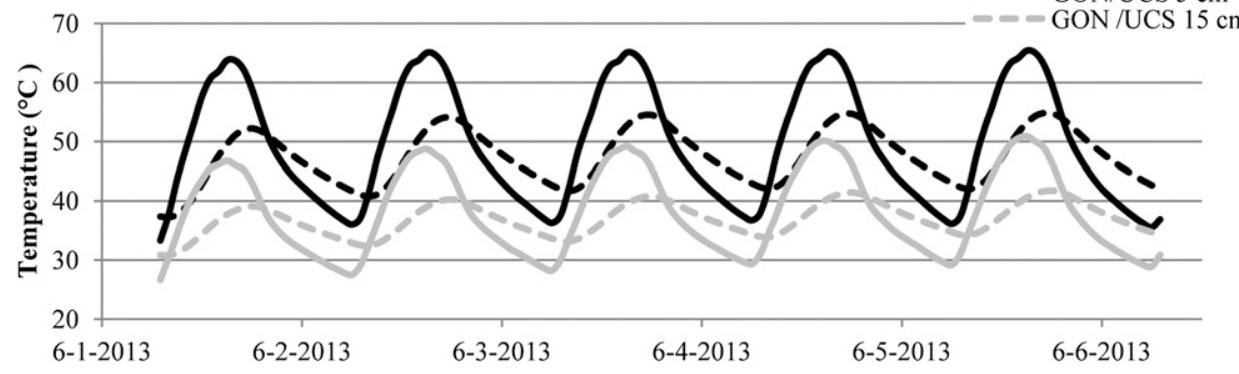

6-1-2013

6-2-2013

6-3-2013

6-4-2013

6-5-2013

6-6-2013

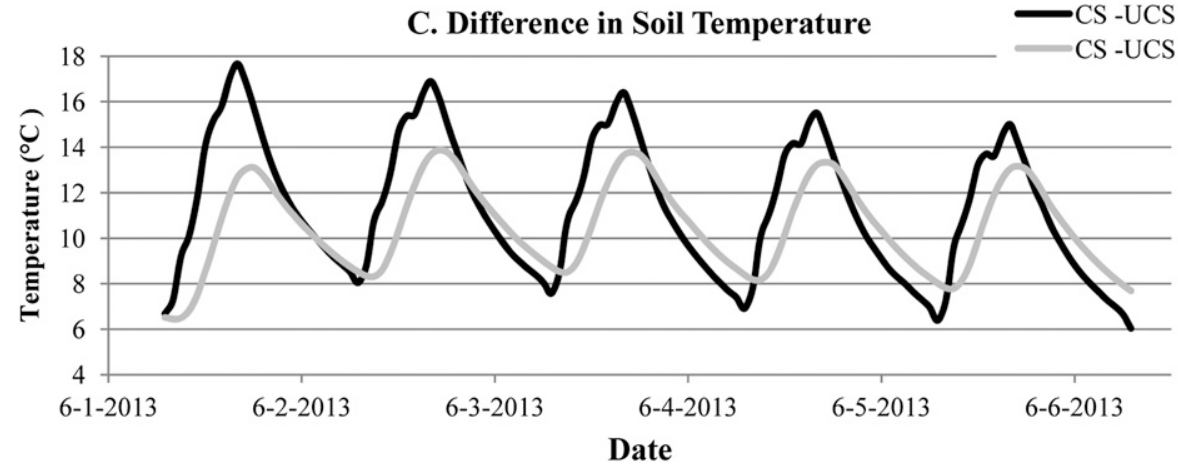

Fig. 2. (A-C) Air and soil temperatures in high tunnels with glazing and soil covered with polyethylene (PE) mulch or uncovered from 1 to 5 June 2013 . GON $=$ glazing on high tunnel; $\mathrm{CS}$ = covered soil; UCS = uncovered soil. AZMET is the outside air temperature from an adjacent weather station.

June through September (Iapichino et al., 2008). Solarization in Costa Rica under high tunnels where soil temperatures reached $60^{\circ} \mathrm{C}$ resulted in $100 \%$ weed control in beds used for hot pepper cultivation (Santos et al., 2008).

The second most effective treatment to raise the soil temperature was the conventional use of PE mulch on moist soil. Previous studies at the University of Arizona Campus Agriculture Center during the month of June resulted in maximum average temperatures of 49 and $50{ }^{\circ} \mathrm{C}$ at $15-\mathrm{cm}$ depths in 1981 and 1982 in plots covered with a 50.8- $\mu \mathrm{m}$ PE tarp (Mihail and Alcorn, 1984). These average temperatures were 3 to $4{ }^{\circ} \mathrm{C}$ higher than those we collected when only the soil was covered with plastic mulch. Thinner PE films are found to be more effective at producing higher temperatures and less expensive than thicker films (Stapleton and Devay, 1986). However, lower soil temperatures during solarization can result from previously amending the soil with compost to improve soil structure as thermal conductivity decreases in soil when pore space between aggregates increases (Usowicz et al., 2013). Contrary, the addition of $10 \%$ compost to soil before solarization increased soil temperatures during solarization compared with unamended soil (Simmons et al., 2013). A maximum soil temperature of $48{ }^{\circ} \mathrm{C}$ at $5-\mathrm{cm}$ depth was reported at $5 \mathrm{~cm}$ in Pakistan, which is lower than those we collected in covered beds in an open field (Usmani and Ghaffar, 1982). These lower temperatures likely resulted from the drip lines being left between the soil and the plastic creating more air space and reducing the solar heating potential. Other potential causes for lower temperatures could be the result of the physical properties of the solarization film, climate, and soil structure. Absorption of radiation and heating of the soil is best when air space between the soil and the plastic is kept at a minimum (Shlevin et al., 2004). Maximum temperatures in covered beds in Australia and in covered and uncovered beds in California were comparable to those that we collected in covered and uncovered beds in an open field (Pullman et al., 1981). Temperatures collected in covered beds at the Campus Agriculture Center in Tucson at 5-cm depth were higher than those collected in Yuma, AZ, during the months of July through September when solar radiation levels are lower than in June (AZMET, 2013; Matheron and Prochas, 2010). Soil heating by solarization is affected by a number of factors including soil moisture, solar irradiation, air temperature, soil properties, color and aggregate size, wind, the size of the air gap between the soil and the glazing, and the properties of the glazing material (Ozores-Hampton et al., 2005; Shlevin et al., 2004; Stapleton, 2000; Usowicz et al., 2013). Clear and transparent PE is used as a result of its low cost and high strength. Mulch made from coextruded low-density polyethylene/ ethylene-vinyl acetate or ethylene vinyl acetate raises soil temperatures at depths greater than $10 \mathrm{~cm}$ in a greenhouse over $50^{\circ} \mathrm{C}$ for a longer duration than low-density PE (Candido et al., 2011).

Keeping the glazing on the high tunnel without covering the beds raised soil temperatures up to and over $45{ }^{\circ} \mathrm{C}$ at 5 -cm depth but not at $15-\mathrm{cm}$ depth. This strategy would 

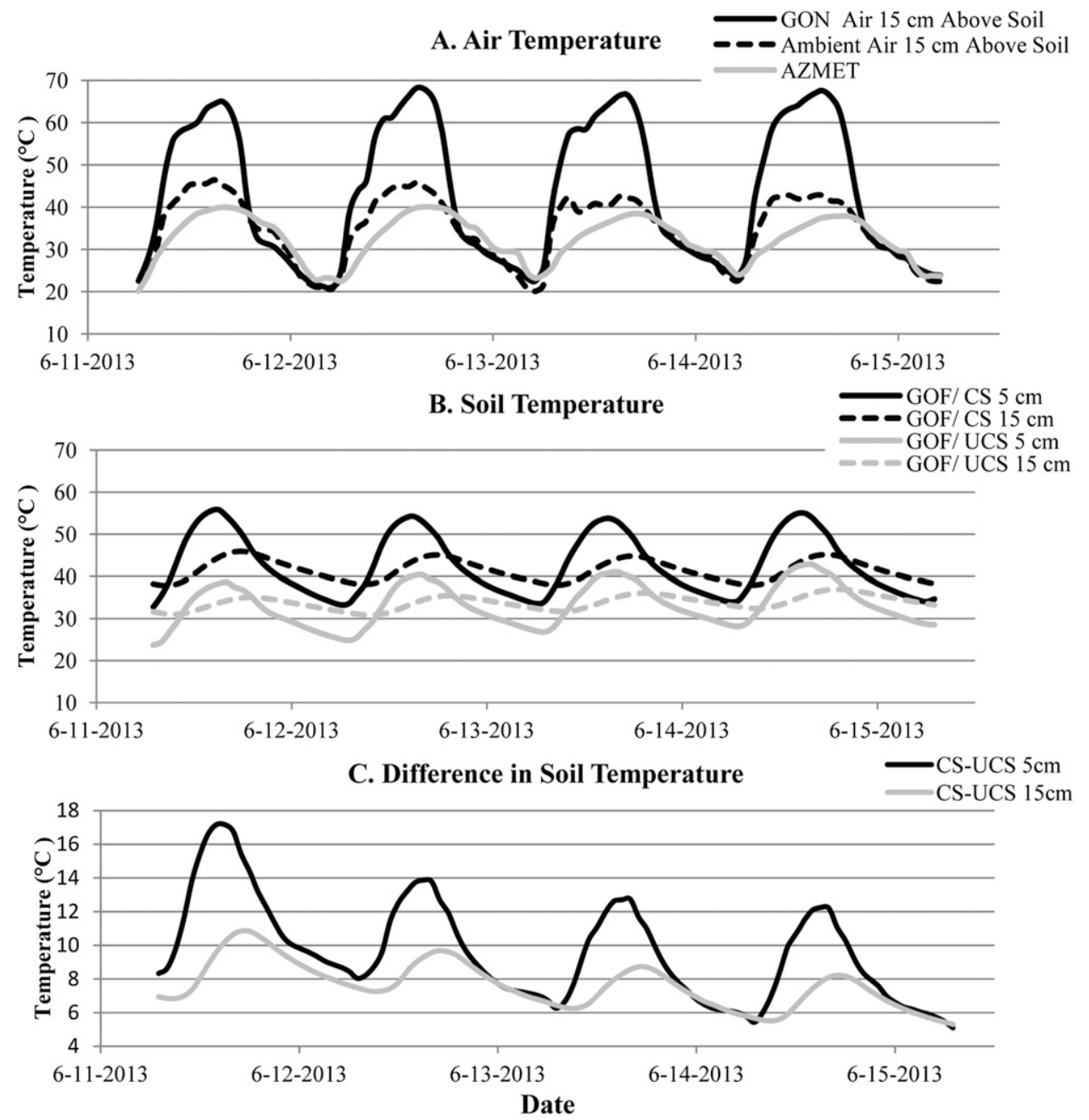

Fig. 3. (A-C) Temperature for air and soil in a high tunnel without glazing, but with soil covered with polyethylene (PE) mulch or uncovered from 11 to 15 June 2013. GOF = glazing off high tunnel; $\mathrm{CS}=$ covered soils; $\mathrm{UCS}=$ uncovered soil. AZMET is the outside air temperature from an adjacent weather station. Air temperature GON $(\mathbf{A})$ is the temperature in the high tunnel with glazing.

require the glazing to be left on the high tunnels for extended periods of time compared with a treatment with the glazing and PE mulch in place. The high tunnel glazing alone was less effective in raising soil temperatures than the conventional PE mulch on the soil surface under open air conditions. The high tunnels had small gaps around the door frame, which allowed air movement inside the tunnels from outside. It is possible that without the structure being airtight, the soil dried more quickly, which would reduce the potential for higher soil temperatures. Without soil mulching, maximum temperatures at 5 - and 15 -cm depth were $\approx 15$ or $11^{\circ} \mathrm{C}$ lower than with soil mulching in a covered high tunnel and effective temperatures to control pests were reached at the shallow depth but not at $15 \mathrm{~cm}$. This might reduce the efficacy of the process depending on the pathogen and pest pressure in the production beds.

Lower soil temperatures for parts of this study may be the result of several factors. On some days solar radiation was obstructed by cloud cover during the experimental period and reduced the amount available for thermal heating. Although held down tight with the lumber, the PE mulch was not buried around the bed and possibly had small breaks in the seal, allowing air to enter and possibly dry the soil. Air entering the high tunnels through small gaps around the door frame might also have contributed to soil drying.

Soil solarization is often carried out for several weeks in field situations (Stapleton, 2000). The goal of our study was to determine the soil temperatures that can be obtained during the hottest time in the southwestern United States. A previous study demonstrated that a 1-month solarization where soil temperatures at $5-\mathrm{cm}$ depth reached 47 and $49{ }^{\circ} \mathrm{C}$ had the same efficacy in controlling fusarium wilt of lettuce (Fusarium oxysporum f. sp. lactucae) as a 2-month solarization in Yuma, AZ (Matheron and Prochas, 2010). The higher soil temperatures that were obtained in our study suggest the potential to shorten the duration of solarizing soil in the southwestern United States during times of highest solar irradiation and clear days.

Soil solarization can be an effective method to control soil pathogens and pests in southern Arizona from late spring through summer when high tunnels are not used for production. During the study period from 24 May through 23 June 2013 soil temperatures to $15-\mathrm{cm}$ depth increased such that disinfestation for many undesirable organisms would be completed in less than 1 week (Table 1). Soil solarization with PE mulch alone would require a longer duration. Solarization with glazing alone was least effective in raising soil temperatures and may not control organisms with a higher temperature tolerance, especially at lower soil depths. High tunnel producers in the low desert areas in the southwestern United States can take advantage of solarization when the soil is fallow during the summer months.

\section{Literature Cited}

Arizona Meteorological Network (AZMET). 2013. 20 July 2013. <http://ag.arizona.edu/azmet/>.

Baker, K.F. and K. Cummings. 1943. Control of Pythium root rot of Aloe variegate by hot-water treatment. Phytopathology 33:736-738.

Candido, V., T. D'Addabbo, V. Miccolis, and D. Castronuovo. 2011. Weed control and yield response of soil solarization with different plastic films in lettuce. Sci. Hort. 130:491-497.

Chase, C.A., T.R. Sinclair, D.O. Chellemi, S.M. Olson, J.P. Gilreath, and S.J. Locascio. 1999. Heat-retentive films for increasing soil temperatures during solarization in a humid, cloudy environment. HortScience 34:1085-1089. 
Coelho, L., D.J. Mithchell, and D.O. Chellemi. 2000. Thermal inactivation of Phytophthora nicotianae. Phytopathology 90:1089-1097.

D’Addabbo, T., V. Miccolis, M. Basile, and V. Candido. 2010. Soil solarization and sustainable agriculture: A review, p. 217-274. In: Lichtfouse, E. (ed.). Sustainable agriculture reviews 3-Sociology, organic farming, climate change and soil science. Springer, London, UK.

Dahlquist, R.M., T.S. Prather, and J.J. Stapleton. 2007. Time and temperature requirements for weed seed thermal death. Weed Sci. 55:619625 .

Dyer, A.T., C.E. Windels, R.D. Cook, and K.J. Leonard. 2007. Survival dynamics of Aphanomyces cochliodes oospores exposed to heat stress. Phytopathology 97:484-491.

Elmore, C.L., J.J. Stapleton, C.E. Bell, and J.E. Devay. 1997. Soil solarization: A nonpesticidal method for controlling diseases, nematodes, and weeds. Publication no. 21377. University of California. 12 Oct. 2013.<http://vric.ucdavis. edu/pdf/soil_solarization.pdf $>$.

Etxeberria, A., S. Medarte, and S. Larregla. 2011. Thermal inactivation of Phytopthera capsici oospores. Rev. Iberoam. Micol. 28:83-90.

Gill, H.K., R. McSorley, and D.D. Treadwell. 2009. Comparative performance of different plastic films for soil solarization and weed suppression. HortTechnology 19:769-774.

Hartz, T.K., J.E. Devay, and C.L. Elmore. 1993. Solarization is an effective soil disinfestation technique for strawberry production. HortScience 28:104-106.

Iapichino, G., C. Prinzivalli, and F. D’Anna. 2008. Soil solarization as an alternative to methyl bromide fumigation for annual strawberry production in a Mediterranean area. J. Sustain. Agr. 32:365-375.

Juarez-Palacios, C., R. Felix-Gastelum, R.J. Wakeman, E.J. Paplomatas, and J.E. DeVay. 1991. Thermal sensitivity of three species of Phytophthora and the effect of solarization on their survival. Plant Dis. 75:1160-1164.
Katan, J. 1981. Solar heating (solarization) of soil for control of soilborne pests. Annu. Rev. Phytopathol. 19:211-236.

Katan, J., A. Greenberger, H. Alon, and A. Grinstein. 1976. Solar heating by polyethylene mulching for the control of diseases caused by soil-borne pathogens. Phytopathology 66:683-688.

Larson, K.D. 2007. Soil solarization enhancements with high tunnels in southern California. Acta Hort. 842:973-976.

Lichter, A., H.W. Zhou, M. Vaknin, O. Dvir, Y. Zutchi, T. Kaplunov, and S. Lurie. 2003. Survival and responses of Botrytis cinerea after exposure to ethanol and heat. J. Phytopathol. 151:553-563.

Mahrer, Y., R. Avissar, O. Naot, and J. Katan. 1987. Intensified soil solarization with closed greenhouses: Numerical and experimental studies. Agr. For. Meteorol. 41:325-334.

Matheron, M.E. and M. Prochas. 2010. Evaluation of soil solarization and flooding as management tools for fusarium wilt of lettuce. Plant Dis. 94:1323-1328.

McLean, K.L., J. Swaminathan, and A. Stewart. 1999. Increasing soil temperature to reduce sclerotial viability of Sclerotium cepivorum in New Zealand soils. Soil Biol. Biochem. 33:137-143.

Mihail, J.D. and S.M. Alcorn. 1984. Effects of soil solarization on Macrophomia phaseolina and Sclerotium rolfsii. Plant Dis. 68:156-159.

Nelson, P.E. and S. Wilhelm. 1958. Thermal death range of Verticillium albo-atrum. Phytopathology 48:613-616.

Ozores-Hampton, M., P.A. Stansly, R. McSorley, and T.A. Obreza. 2005. Effects of long-term organic amendments and soil solarization on pepper and watermelon growth, yield, and soil fertility. HortScience 40:80-84.

Pinkerton, J.N., P.R. Bristow, G.E. Windom, and T.W. Walters. 2009. Soil solarization as a component of an integrated program for control of raspberry root rot. Plant Dis. 93:452-458.

Pullman, G.S., J.E. DeVay, and R.H. Garber. 1981. Soil solarization and thermal death: A logarithmic relationship between time and temperature for four soilborne plant pathogens. Phytopathology 71:959-964.

Santos, B.M., J.E. Mora-Bolaños, and J.A. SolórzanoArroyo. 2008. Impact of solarization and soil fumigants on hot pepper production in high tunnels. Asian J. Plant Sci. 7:113-115.

Sherwood, R.T. 1970. Physiology of Rhizoctonia solani, p. 69-92. In: Parmeter, Jr., J.R. (ed.). Rhizoctonia solani, Biology and pathology. Univ. California Press, Berkeley, CA.

Shlevin, E., Y. Mahrer, and J. Katan. 2004. Effect of moisture on thermal inactivation of soilborne pathogens under structural solarization. Phytopathology 94:132-137.

Simmons, C. W., H. Guo, J.T. Claypool, M.N. Marshall, K.M. Perano, J.J. Stapleton, and J.S. VanderGheynst. 2013. Managing compost stability and amendment to soil to enhance soil heating during soil solarization. Waste Mgt. 33:1090-1096.

Stapleton, J. 2000. Soil solarization in various agricultural production systems. Crop Prot. 19:837-841.

Stapleton, J.J. and J.E. Devay. 1986. Soil solarization: A non-chemical approach for management of plant pathogens and pests. Crop Prot. 5:190-198.

Stapleton, J.J., T.S. Prather, S.B. Mallek, T.S. Ruiz, and C.L. Elmore. 2002. High temperature solarization for production of weed-free container soils and potting mixes. HortTechnology 12:697-700.

Usmani, S.M.H. and A. Ghaffar. 1982. Polyethylene mulching of soil to reduce viability of sclerotia of Sclerotium oryzae. Soil Biol. Biochem. 14:203-206.

Usowicz, B., J. Lipiec, J.B. Usowicz, and W. Marczewski. 2013. Effects of aggregate size on soil thermal conductivity: Comparison of measured and model-predicted data. Intl. J. Heat Mass Transfer 57:536-541.

Wang, K.H. and R. McSorely. 2008. Exposure time to lethal temperatures for Meloidogyne incognita suppression and its implication for solarization. J. Nematol. 40:7-12. 